\title{
Paroxysmal hypnogenic dyskinesia
}

血

Supplemental data at Neurology.org
A 13-year-old girl presented with abnormal movements occurring during sleep, consisting of stiffening of the limbs bilaterally and random flailing of the arms and legs lasting less than 1 minute several times per night (video on the Neurology ${ }^{\circledR}$ Web site at Neurology.org). Daytime episodes were reported, but rare. After workup, she was given a diagnosis of paroxysmal hypnogenic dyskinesia (PHD), was started on oxcarbazepine, and became free of episodes. PHD typically occurs during non-REM sleep ${ }^{1}$; spells are short in duration but may cause fragmented sleep. There is no established treatment and medical management is based on treatment of other more common paroxysmal dyskinesias.

Leonardo Almeida, MD, Leon S. Dure, MD

From the Department of Neurology (L.A., L.S.D.) and the Department of Pediatrics, Division of Pediatric Neurology (L.S.D.), University of Alabama at Birmingham.

Author contributions: Dr. Leonardo Almeida: acquisition of data, literature review. Dr. Leon Dure: conception and revision of manuscript, overall case report supervision.

Study funding: No targeted funding reported.

Disclosure: The authors report no disclosures relevant to the manuscript. Go to Neurology.org for full disclosures.

Correspondence to Dr. Dure: LDure@peds.uab.edu

1. Benbir G, Senturk A, Tan F, Karadeniz D. Polysomnographic recording of a child with paroxysmal hypnogenic dyskinesia and NREM parasomnia. Sleep Med 2013;14:215-216. 


\title{
Neurology
}

\author{
Paroxysmal hypnogenic dyskinesia \\ Leonardo Almeida and Leon S. Dure \\ Neurology 2014;82;1935 \\ DOI 10.1212/WNL.0000000000000451
}

This information is current as of May 26, 2014

\begin{tabular}{ll}
$\begin{array}{l}\text { Updated Information \& } \\
\text { Services }\end{array}$ & $\begin{array}{l}\text { including high resolution figures, can be found at: } \\
\text { http://n.neurology.org/content/82/21/1935.full }\end{array}$ \\
Supplementary Material & $\begin{array}{l}\text { Supplementary material can be found at: } \\
\text { http://n.neurology.org/content/supp1/2014/05/24/82.21.1935.DC1 }\end{array}$ \\
This article cites 1 articles, 0 of which you can access for free at: \\
http://n.neurology.org/content/82/21/1935.full\#ref-list-1 \\
This article, along with others on similar topics, appears in the \\
following collection(s): \\
All Movement Disorders \\
http://n.neurology.org/cgi/collection/all_movement_disorders \\
Information about reproducing this article in parts (figures,tables) or in \\
its entirety can be found online at: \\
http://www.neurology.org/about/about_the_journal\#permissions \\
Permissions \& Licensing & $\begin{array}{l}\text { Information about ordering reprints can be found online: } \\
\text { http://n.neurology.org/subscribers/advertise }\end{array}$ \\
\hline Reprints &
\end{tabular}

Neurology ${ }^{\circledR}$ is the official journal of the American Academy of Neurology. Published continuously since 1951, it is now a weekly with 48 issues per year. Copyright (O 2014 American Academy of Neurology. All rights reserved. Print ISSN: 0028-3878. Online ISSN: 1526-632X.

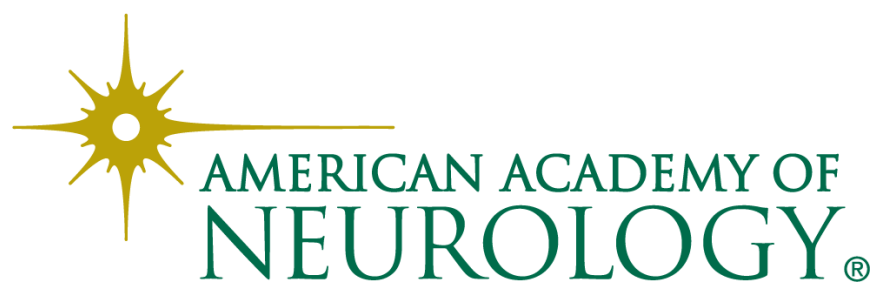

